\title{
Research on the IMPACT OF Christianity on Roman LAW IN the INTERWAR Poland: FranciszeK Bossowski's VieWs
}

Franciszek Bossowski was one of the most renowned Polish Roman Law specialists at the turn of the $19^{\text {th }}$ and $20^{\text {th }}$ century. ${ }^{1}$ Initially linked with the Jagiellonian University, after World War I he relocated to Vilnius, where the Stefan Batory University had resumed operations. His research activity was extremely prolific. He participated in numerous conferences and meetings, and was a member of scientific associations. ${ }^{2}$ Most importantly, however, F. Bossowski printed numerous works dedicated to Roman law and civil law. In his research, carried out in the interwar Poland, he attempted to comprehensively examine the impact of Christianity on Roman law. ${ }^{3}$ During this period of time, the research on a more detailed issue, namely the relation between marriage and Christianity, was conducted by Henryk Insadowski, who published his work entitled Roman Law on Marriage and Christianity. This was accompanied by sever-

* Ph.D., Assistant Professor of University of Silesia; e-mail: grzegorz.nancka@us.edu.pl, ORCID ID: https:/ / orcid.org/0000-0002-9911-7473.

1 Franciszek Bossowski was born in Stryszawa near Żywiec on 12 April 1897 and died on 3 May 1940 in Kraków. He graduated from the Faculty of Law and Administration, Jagiellonian University in Kraków, where he also earned his venia docendi in Roman law. After the Stefan Batory University in Vilnius had resumed its operations, he was appointed to work as an assistant professor there. As for his biography cf. K. Szczygielski, Franciszek Bossowski (1879-1940). Szkic do biografii, Miscellanea Historico-Iuridica 2009, vol. 7, pp. 71-83.

2 Cf. K. Szczygielski, Franciszek Bossowski (1879-1940).., p. 78.

3 Cf. F. Bossowski, Wptyw chrześcijaństwa na rozwój prawa rzymskiego, Przegląd Prawa i Administracji 1925, vol. 50, pp. 307-317; idem, Wptyw sądownictwa polubownego biskupów na prawo rzymskie, Rocznik Prawniczy Wileński 1933, no. 6, pp. 11-42.

4 Cf. H. Insadowski, Rzymskie prawo matżeńskie a chrześcijaństwo, Lublin 1935; cf. also: A. Dębiński, Kościót i prawo rzymskie, Lublin 2008, p. 13. 
al other, less comprehensive publications, dedicated to relations between law and Christianity, including a short text by Hieronim Markowski entitled The Nazareth Inscription and the Beginnings of Christianity. ${ }^{5}$ However, F. Bossowski was the only researcher who not only attempted to review the existing views presented in scholarly literature but also strove to present his own position on the matter. The objective of this article is to recount the views of this Vilnius-based Roman law scholar, especially since the research on the impact of Christianity on Roman law is still in its growing phase and so it appears legitimate to draw attention to the existing achievements of the Polish Roman law researchers in this regard.

In his works, F. Bossowski did not withhold that examination of the impact of Christianity on Roman law was exceptionally complicated. ${ }^{6}$ The Christian Church, which ever since the end of the $2^{\text {nd }}$ century had continued to strengthen its position, had the support of both the intelligentsia and lower social classes. For the former, it was a moral authority whereas for the latter, it offered the idea of brotherhood of all people. ${ }^{7}$ Emperor Constantine the Great, who lived at the turn of the $3^{\text {rd }}$ and $4^{\text {th }}$ century, was well aware of the power of Christianity and in his fight for the throne won over the support of Christians and consequently emerged victorious. ${ }^{8}$ This, according to F. Bossowski, made the emperor decide to "lean on this force, whose strength he came to know during his fight against his opponents." ${ }^{\prime 9}$ It is beyond any doubt that Constantine lived in times that were revolutionary from the perspective of a changing perception of the emperor's role. The cult of emperor-as-god, existing and functioning during the reign of the previous Emperor Diocletian, was then beginning to die out. Meanwhile, the Catholic Church gained even more prominence after Constantine had signed the Edict of Milan. ${ }^{10}$ It is also for that reason that

5 Cf. H. Markowski, Edykt nazareński a początki chrześcijaństwa, Sprawozdania Poznańskiego Towarzystwa Przyjaciół Nauk 1937, vol. 11, pp. 31-34.

6 F. Bossowski, Wptyw chrześcijaństwa..., p. 307.

7 Ibidem, p. 308.

8 Ibidem, p. 309; cf. S. Riccobono, L'influenza del Cristianesimo nella codificazione di Giustiniano, Rivista di Scienza “Scientia" 1909, vol. 5, no. 1, p. 127.

9 F. Bossowski, Wptyw chrześcijaństwa..., p. 309.

10 Ibidem, p. 310; cf. W. Abraham, Edykt Medyolański. W 1600-letnia rocznice, Przegląd Powszechny 1913, vol. 30, no. 7 [119], pp. 1-31; A. Żurek, Chrystianizacja prawa po "Edykcie Mediolańskim", Vox Patrum 2014, vol. 61, no. 34, pp. 73-88; A. Dębiński, Kościót i prawo rzymskie, pp. 28-38. 
the reign of Emperor Constantine should be considered as revolutionary, not just due to the growing importance of Christianity, but also its impact on Roman law. ${ }^{11}$

Franciszek Bossowski maintains that Christianity had a significant impact on the transformation of Roman law. ${ }^{12}$ However, that calls into question the views held by Salvatore Riccobono, who was of the opinion that the impact of Christianity on Roman law was very extensive. ${ }^{13}$ According to the Vilnius-based scholar, it is indeed difficult to imagine that - as Riccobono claims - the Church even before Justinian the Great had reviewed the entire, unstructured material from the area of Roman private law. ${ }^{14}$ It is equally doubtful that it presented proposals for changes on those grounds. ${ }^{15}$ What is more, F. Bossowski believes that S. Riccobono failed to demonstrate a causal link between the interpolations of the sources referred to in his work and Christianity. Franciszek Bossowski's doubts concern, in particular, the scope of impact of Christianity on Roman law and, what follows, the importance of the impact of other factors. ${ }^{16}$ Those difficulties are related to the fact that the ideas and postulates characteristic of Christianity also appear in the works of pagan authors. ${ }^{17}$ Therefore, according to F. Bossowski, another hypothesis is far more probable. It is connected with the activity of bishops who exercised judiciary power in civil cases. Franciszek Bossowski claims that this was extremely important for the impact of Christianity on Roman law. In other words, the activity of bishops determined the scope of changes that were taking place in Roman law. It encompassed the issues that were subject to jurisdiction of the episcopal court. Accordingly, parties engaged in a dispute referred to the episcopal court which, on the basis of the specific facts of the case, formulated certain postulates. Then, thus formulated proposals took root in the society and - as F. Bossowski points out - permeated to Justinian's Codification. ${ }^{18}$ The bishops exercising judicial power decided in cases sub-

\footnotetext{
11 F. Bossowski, Wptyw chrześcijaństwa..., p. 310.

12 Idem, Wptyw sadownictwa polubownego..., p. 22.

13 Ibidem, p. 24; cf. also: S. Riccobono, L'influenza..., pp. 127-129.

14 F. Bossowski, Wptyw sądownictwa polubownego..., p. 24.

15 Ibidem, p. 25.

16 Ibidem, p. 22.

17 Ibidem, p. 23.

18 Ibidem, p. 25.
} 
mitted to them according to their conscience, and not the law. ${ }^{19}$ This, according to the scholar, proves that this was not a case of statutory activity of the Church. ${ }^{20}$ One must not forget, either, that judgments issued by ecclesiastical courts constituted an enforcement order for state authorities (C. $1,4,8),{ }^{21}$ and the growing authority of the Church led to bishops gaining extensive powers in penal cases, namely interceding for the sentenced and exercising supervision over prisons. ${ }^{22}$

According to F. Bossowski, there is no denying that Christian influences were very strong in marital law. Although initially the Church did not hold monopoly over those matters, as time went by, its exclusive control became more and more prominent. It is beyond any doubt that the key issue in this regard was the protection of the matrimony. It manifested itself e.g. in extending the scope of persons who could be punished for adultery (adulterium). In addition to women, men, could be sentenced, too. ${ }^{23}$ That, however, did not mark the end of the impact of Christianity on Roman law. As F. Bossowski points out, classical Roman law professed the principle of consortium omnis vitae, divini et humani iuris communicatio, as a result of which it created no obstacles to divorce. ${ }^{24}$ However, because of the Christian ideology, Roman law started to counteract divorces, especially groundless ones. The factor, that was meant to prevent divorce,

19 Ibidem.

20 Ibidem.

21 F. Bossowski, Wptyw chrześcijaństwa..., p. 310. Cf. C. 1,4,8: Episcopale iudicium sit ratum omnibus, qui se audiri a sacerdotibus elegerint, eamque illorum iudicationi adhibendam esse reverentiam, quam vestris referre necesse est potestatibus, a quibus non licet provocare. Per iudicium quoque officia, ne sit cassa episcopalis cognitio, definitioni exsecutio tribuatur. * ARCAD. HONOR. ET THEODOS. AAA. THEODORO PP. ${ }^{*}<A 408$ D. ID. DEC. BASSO ET PHILIPPO CONSS.> [An episcopal trial shall be valid for all who choose to be tried by bishops, and the same reverence must be paid to its adjudication as to your powers, from which it is not permitted to appeal. Also, lest episcopal hearings be in vain, their rulings must be carried out by the official staffs of the governors. *Emperors Arcadius. Honorius, and Theodosius Augusti to Theodorus Praetorian Prefect. * Given December 13, in the consulship of Bassus and Philippus (408)], as translated in: The Codex of Justinian. A New Annotated Translation, with Parallel Latin and Greek Text, vol. 1. Introductory Matter and Books I-III, ed. B.W. Frier, Cambridge 2016, p. 153.

${ }^{22}$ F. Bossowski, Wpływ chrześcijaństwa..., p. 310.

${ }^{23}$ Ibidem, p. 312; cf. also: D. Stolarek, Adultera w świetle lex Iulia de adulteriis coërcendis, Lublin 2012.

24 Ibidem, p. 312; cf. S. Riccobono, L'influenza..., p. 128. 
arose from negative financial consequences for those who intended to dissolve their matrimony. ${ }^{25}$ Changes pushed by Christianity also included restricting the admissibility of cohabitation in a conjugal relationship. ${ }^{26}$

Christianity, as F. Bossowski stresses, also had a positive impact on the situation of women. First of all, the ideology intended to eliminate the discrimination of women as regards the right of inheritance. This is particularly prominent in Justinian law, as evidenced by fragments of title 58 of Book 6 of Justinian Code (C. 6,58,14 and C. 6,58,15). ${ }^{27}$ Another manifestation of the protection of women is the counteracting of compelled prostitution of female slaves, which led to strengthening the protection of female slaves in Theodosian Code (C. Th. 15,8,2). ${ }^{28}$

25 F. Bossowski, Wptyw chrześcijaństwa..., p. 312; cf. E. Cuq, Les institutions juridiques des romains, vol. 2. Le droit classique et le droit du Bas-Empire, Paris 1908, pp. 803-804; O. Lenel, Geschichte und Quellen des römischen Rechts, in: F. Holtzendorff, J. Kohler, Enzyklopädie der Rechtswissenschaft in systematischer Bearbeitung, vol. 1, München-Leipzig-Berlin 1915, p. 375.

26 F. Bossowski, Wptyw sądownictwa polubownego..., p. 24.

27 F. Bossowski, Wptyw chrześcijaństwa..., p. 313; cf. F. von Woess, Das römische Erbrecht und die Erbanwärter: ein Beitrag zur Kenntnis des römischen Rechtsleben vor und nach der Constitutio Antoniniana, Berlin 1911.

28 Cf. C. Th. 15,8,2 (Impp. Theodosius et Valentinianus aa. Florentio praefecto praetorio): Lenones patres et dominos, qui suis filiis vel ancillis peccandi necessitatem imponunt, nec iure frui dominii nec tanti criminis patimur libertate gaudere. Igitur tali placet eos indignatione subduci, ne potestatis iure frui valeant neve quid eis ita possit adquiri. Sed ancillis filiabusque, si velint, conductisve pro paupertate personis, quas sors damnavit humilior, episcoporum liceat, iudicum etiam defensorumque implorato suffragio omni miseriarum necessitate absolvi, ita ut, si insistendum eis lenones esse crediderint vel peccandi ingerant necessitatem invitis, non amittant solum eam quam habuerant potestatem, sed proscripti poenae mancipentur exilii metallis addicendi publicis, quae minor poena est, quam si praecepto lenonis cogatur quispiam coitionis sordes ferre, quas nolit. Dat. XI kal. mai. Felice et Tauro conss. (428 apr. 21) [(Emperors Theodosius and Valentinian Augustuses to Florentius, Praetorian Prefect): If fathers or masters should be procurers and should impose upon their daughters or female slaves the necessity of sinning. We do not allow such procurers to enjoy the right of ownership or to rejoice in the licence of so great criminality. It is Our pleasure, therefore, that such procurers shall be deprived by Our indignation, and they shall not be able to enjoy the right of control over their daughters or slaves, or to acquire any gain from them in this manner. But if the slaves and daughters so wish, as well as the persons hired on account of poverty and condemned to such a condition by their humble lot, they shall be permitted to implore the aid of bishops, judges, and defenders, to be released from all the bonds of their miseries. If the procurers should be suppose that they may insist or if they should compel the women to undergo the necessity of sinning against they will, they shall not only forfeit all the power which they had over 
Franciszek Bossowski furthermore claimed that the aforementioned arbitration by bishops was not limited to transforming Roman law in the spirit of Christianity, but also to reception of numerous Greek law institutions by post-classical Roman law. ${ }^{29} \mathrm{He}$ argued that one proof in support of his thesis was the evolution of manumissionis in sacrosanctis ecclesia. This manner of liberation, which derived from Greece, consisted in a herald announcing before a municipality the fact that the person liberated had been granted freedom. ${ }^{30}$ The scholar stressed that in manumissio in sacrosanctis ecclesiae, the secular municipality was replaced by Christian municipality, and that Constantine the Great in C. Th. 4,7,1 pr-1 merely regulated an existing practice. ${ }^{31}$

them, but they shall also be proscribed and delivered to the punishment of being assigned to exile in the public miners. Such a punishment is less severe than that of a woman who is compelled, and the command of a procurer, to tolerate the sordidness of a coition which she does not wish. Given on the eleventh day before the kalends of May in the year of the consulship of Felix and Taurus - April 21, 428], as translated in: The Theodosian Code and Novels, and the Sirmondian Constitutions. A Translation with Commentary, Glossary, and Bibliography, ed. C. Pharr, New Jersey 2001, p. 435.

29 F. Bossowski, Wptyw sadownictwa polubownego..., p. 28.

30 Ibidem, p. 28; cf. J. Partsch, Mitteilungen aus der Freiburger Papyrussammlung, vol. 2. Juristische Texte der römischen Zeit, Heidelberg 1916, p. 44.

31 F. Bossowski, Wptyw sadownictwa polubownego..., p. 28; cf. C. Th. 4,7,1 pr. [= brev. 4.7.1 pr.] (Imp. Constantinus a. Osio episcopo): Qui religiosa mente in ecclesiae gremio servulis suis meritam concesserint libertatem, eandem eodem iure donasse videantur, quo civitas Romana solennibus decursis dari consuevit. Sed hoc dumtaxat*iis, qui sub adspectu antistitum dederint, placuit relaxari. [(Emperor Constantine Augustus to Bishop Hosius): If any person with pious intention should grant deserved freedom to his favorite slaves in the bosom of the Church, he shall appear to give it with the same legal force as that with which Roman citizenship formerly was customarily bestowed under observance of the usual formalities. But it is Our pleasure that such right to manumit in the churches shall be allowed only to those persons who give freedom under the eyes of the bishops], as translated in: The Theodosian Code..., ed. C. Pharr, p. 87; C. Th. 4,7,1,1 [= brev. 4,7,1,1]: Clericis autem amplius concedimus, ut, quum suis famulis tribuunt libertatem, non solum in conspectu ecclesiae ac religiosi populi plenum fructum libertatis concessisse dicantur, verum etiam quum postremo iudicio libertates dederint, seu quibuscumque* verbis dari praeceperint ita ut ex die publicatae voluntatis, sine aliquo iuris teste vel interprete, competat directa libertas. Dat. xiv. kal. mai. Crispo ii. et Constantino ii. coss. [To clerics, moreover, We further grant that when they bestow freedom in their own household slaves, not only shall they be said to have given the complete enjoyment of such freedom when they have granted it in sight of the Church and the religious congregation, but also when they have conferred freedom in a last will or ordered it to be given by any words, so that the slaves shall receive their directly on the day of 
Franciszek Bossowski believed that the activity of bishops as arbitrators had a major impact on private property rights. ${ }^{32}$ The scholar formulates an assertion that interpolations conducted in Justinian's Codification constitute the acknowledgment of changes in law made through a custom established as a result of judicature. ${ }^{33}$ This is evidenced by e.g. the relation between the classical rule of qui iure suo utitur neminem laedit and the principle prodesse enim sibi unusquisque, dum alii noc nocet, non prohibetur, as laid down in a fragment of Ulpian's opinion in D. 39,3,1,11. ${ }^{34}$ The scholar explains that both principles are contradictory and wonders what the reason was for that regulation laid down in D. 39,3,1,11. He argues that, while it is possible that the regulation was affected by special hydrographic conditions, in his opinion it resulted from other factors. He believes that when formulating that principle of law, the law-maker was influenced by the Christian ideology, which required that one should respect one's neighbour's interests while exercising one's own rights. ${ }^{35}$ Indeed, the argumentation presented in the fragment does not refer to the needs of respective provinces that suffer from a shortage of water, but to arguments related to the position of a neighbour. ${ }^{36}$ Franciszek Bossowski stresses that bishops who decided on disputes connected with the use of water based their decisions not on provisions of Roman law but rather on

the publication of the will, without the necessity of any witness or intermediary of the law. Given on the fourteenth day before the kalend of May in the year of the second consulship of Crispus and Constantine Caesars - April 18, 321], as translated in: The Theodosian Code..., ed. C. Pharr, pp. 87-88; cf. also: I. Żeber, O problemie klasyfikacji "manumissio in ecclesia", in: Prawo wyznaniowe. Przeszłość i teraźniejszość, ed. J. Koredczuk, Wrocław 2008, pp. 97-134.

32 F. Bossowski, Wptyw chrześcijaństwa..., p. 314.

33 Ibidem, p. 314.

34 D. 39,3,1,11 (Ulpianus libro quinquagensimo tertio ad edictum): Idem aiunt aquam pluviam in suo retinere vel superficientem ex vicini in suum derivare, dum opus in alieno non fiat, omnibus ius esse (prodesse enim sibi unusquisque, dum alii non nocet, non prohibetur) nec quemquam hoc nomine teneri. [The same authorities say that everyone has the right to retain rainwater on his own property and to channel surface rainwater from his neighbor's property onto his own, provided that no work is done on someone else's property, and that no one can be held liable on this account, since no person is forbidden to profit himself as long as he harms nobody else in so doing], as translated in: The Digest of Justinian, vol. 3, ed. A. Watson, Philadelphia 1998, p. 396.

35 F. Bossowski, Wptyw chrześcijaństwa..., pp. 314-315; cf. S. Riccobono, L'influenza..., p. 137.

36 F. Bossowski, Wptyw sadownictwa polubownego..., p. 26. 
provisions of local water law. They substantiated their judgments not with the hydrographic situation of the state but rather with postulates of conscience. As the scholar claims, this sort of consistency on the part of ecclesiastical courts led to those principles permeating to Justinian's Codification and to the formulation of that, as opposed to another, regulation. ${ }^{37}$

Franciszek Bossowski clams that a similar situation took place in the fragment of a statement by Celsus in D. 6,1,38, where the prohibition of ius tollen$d i$ for persecution was also formulated. ${ }^{38}$ Franciszek Bossowski stresses that the prohibition of persecution was not known to classical Roman law and only emerged for the first time in Justinian law. ${ }^{39}$ The scholar is of the opinion that the prohibition of exercising one's own right for persecution, as was

37 Ibidem, p. 27.

38 F. Bossowski, Wptyw chrześcijaństwa..., p. 315; D. 6,1,38 (Celsus libro tertio digestorum): In fundo alieno, quem imprudens emeras, aedificasti aut conseruisti, deinde evincitur: bonus iudex varie ex personis causisque constituet. finge et dominum eadem facturum fuisse: reddat impensam, ut fundum recipiat, usque eo dumtaxat, quo pretiosior factus est, et si plus pretio fundi accessit, solum quod impensum est. finge pauperem, qui, si reddere id cogatur, laribus sepulchris avitis carendum habeat: sufficit tibi permitti tollere ex his rebus quae possis, dum ita ne deterior sit fundus, quam si initio non foret aedificatum. constituimus vero, ut, si paratus est dominus tantum dare, quantum habiturus est possessor his rebus ablatis, fiat ei potestas: neque malitiis indulgendum est, si tectorium puta, quod induxeris, picturasque corradere velis, nihil laturus nisi ut officias. finge eam personam esse domini, quae receptum fundum mox venditura sit: nisi reddit, quantum prima parte reddi oportere diximus, eo deducto tu condemnandus es. [You inadvertently bought land belonging to another, built or planted on it, and then were evicted by the owner; the good judge's order will vary according to the persons involved and the facts of the case. Suppose the owner would have done the same as you. In that case, in order to get his land back, he must pay your expenses to the extent that the value of the land has been increased, or if the increase in value is more than the expenses, then only the amount you expended. Suppose the owner is a poor man who, if made to pay such a sum, would have to give up his household gods and ancestral graves. In that case, it is enough that you be allowed to take away what you can from the building materials, so long as the land is not thus put in a worse condition than it would be in, if there had been no building. Our decision is that if the owner is prepared to pay the possessor as much as he would have if he took the materials away, he should have the power to do so. There must be no indulgence to malice. If, say, you want to scrape off plaster which you have put on walls, and deface pictures, that will serve no purpose but to annoy. Suppose the owner is someone who wants to sell the land as soon as he gets it back; unless he pays what we said should be paid in the first case, then the judgment against you is reduced by that amount.], as translated in: The Digest of Justinian, vol. 1, ed. A. Watson, Philadelphia 1998, p. 207.

39 F. Bossowski, Wptyw sądownictwa polubownego..., p. 26; cf. S. Riccobono, L'influenza..., pp. 133, 136-141. 
then introduced, is a revolutionary solution, given the regulations existing before its introduction. He claims that it is innovative in that "interest not protected by subjective rights is given precedence over interest protected by subjective rights, solely on the basis of subjective criteria, whereby the former is considered more legitimate than the latter." ${ }^{40}$ Accordingly, he concludes that this solution is an exception to a rule. ${ }^{41}$

According to F. Bossowski, another principle that developed thanks to Christian influences is the principle nemo ex aliena iactura locupletior fieri debet. He stresses that, pursuant to Roman law regulations, "subjective right $[. .$.$] serves to protect such interests of the entitled individual which$ deserve protection due to collective general-social interests." 42 The Christian ideology not only rejected the cult of earthly possessions but was also aware of human imperfection. It was therefore necessary to introduce such civil law which would not only protect an individual against lawlessness, but which would, in the first place, protect a person against harm caused by another person. ${ }^{43}$ Franciszek Bossowski believes that a consequence of that principle is an obligation introduced by Justinian to return fructus extantes by their holder in good faith. ${ }^{44}$ For the same reason, good faith of the holder was required not just at the time of acquisition of things but also each time fruit is collected. ${ }^{45}$ The scholar stresses that a consequence

40 F. Bossowski, Wpływ chrześsijaństwa..., p. 315.

41 Ibidem.

42 Ibidem; cf. S. Riccobono, L'influenza..., p. 140; G. Baviera, Concetto e limiti dell'influenza del Cristianesimo sul diritto romano, in: Mélanges Paul Frédéric Girard. Études de droit romain dédiées à M.P.F. Girard à l'occasion du 60e anniversaire de sa naissance (26 octobre 1912), vol. 1, Paris 1912, pp. 97-98.

43 F. Bossowski, Wptyw chrześcijaństwa..., p. 315.

44 Ibidem.

45 D. 22,1,25,2 (Iulianus libro septimo digestorum): Bonae fidei emptor sevit et antequam fructus perciperet, cognovit fundum alienum esse: an perceptione fructus suos faciat, quaeritur. respondi, bonae fidei emptor quod ad percipiendos fructus intellegi debet, quamdiu evictus fundus non fuerit: nam et servus alienus quem bona fide emero tamdiu mihi ex re mea vel ex operis suis adquiret, quamdiu a me evictus non fuerit. [A buyer in good faith sowed seed and, before he gathered the fruits, discovered that the land was another's. Does he acquire fruits by gathering? I replied that a person is a buyer in good faith for the purpose of taking fruits until evicted. A slave whom I buy in good faith acquires for me from my assets and his labor so long as he is not evicted from my possession.], as translated in: The Digest of Jutinian, vol. 2, ed. A. Watson, Philadelphia 1998, p. 181; D. 41,1,23,2 (Ulpianus libro quadragensimo tertio ad Sabinum): Generaliter dicendum est, quod ex re sua, hoc est eius cui bona fide quis servit, ei adquirere non potest, sibi eum adquisiturum, quod autem non ex re eius sibi adquirere non potest, 
of that regulation was a later-formulated principle of canon law which requires good faith for the entire time needed for prescription. ${ }^{46}$

An important tendency revealed in the influence of Christianity on Roman law is the desire to abstain from the sin of unjust enrichment at someone else's cost, which manifests itself e.g. in ius tollendi granted to a holder in bad faith, or in extension of the application of condictio sine causa. ${ }^{47}$ The idea of Christian brotherhood is also visible in changes concerning morae creditoris in the statement by Ulpian in D. 18,6,3,1 (si tamen cum posset effundere, non effudit, laudandus est potius). ${ }^{48}$

According to F. Bossowski, it is also worth mentioning that sources encompass a number of decisions issued against heretics. Examples, he believed, include those laid down in title 5 of Book 1 of Justinian Code (C. 1,5) De Haereticis et Manichaeis et Samaritis. Franciszek Bossowski believes that those regulations cannot be unequivocally attributed to the impact of

ei adquisiturum, cui bona fide servit. [It is to be said generally that what he cannot acquire for his master in good faith from the latter's resources he will acquire for himself and what he cannot acquire for himself not from the latter's resources, he acquires for the person to whom he is in servitude in good faith.], as translated in: The Digest of Justinian, vol. 4, ed. A. Watson, Philadelphia 1998, p. 7.

46 F. Bossowski, Wpływ chrześcijaństwa..., pp. 315-316.

47 Idem, Wptyw sądownictwa polubownego..., pp. 25-26; cf. S. Riccobono, L'influenza..., pp. 134-135, 142.

48 D. 18,6,1,3 (Ulpianus libro vicesimo octavo ad Sabinum): Licet autem venditori vel effundere vinum, si diem ad metiendum praestituit nec intra diem admensum est. effundere autem non statim poterit, priusquam testando denuntiet emptori, ut aut tollat vinum aut sciat futurum, ut vinum effunderetur. si tamen, cum posset effundere, non effudit, laudandus est potius: eapropter mercedem quoque doliorum potest exigere, sed ita demum, si interfuit eius inania esse vasa in quibus vinum fuit (veluti si locaturus ea fuisset) vel si necesse habuit alia conducere dolia. commodius est autem conduci vasa nec reddi vinum, nisi quanti conduxerit ab emptore reddatur, aut vendere vinum bona fide: id est quantum sine ipsius incommodo fieri potest operam dare, ut quam minime detrimento sit ea res emptori. [Now the vendor may legitimately pour the wine away, if he has set a time for its measuring out and it is not measured within that period. He cannot, however, thus pour it away, so to speak, out of hand; he must first warn the purchaser, before witnesses, that he should remove the wine or realize that if he does not, the wine will be poured away. All the same, if he does not pour it away when he would be entitled to do so, he is to be commended; he can further charge rent for his casks, so long as he has an interest in the vessels which hold the wine being empty (as, for instance, if he would have let them out) or if he would have to hire other containers. It is, though, the more appropriate course for him to hire other containers and to hold back the wine until the purchaser pays him the rent thereof or else to sell the wine in good faith; in short, he should mitigate the purchaser's loss so far as he can without detriment to himself.], as translated in: The Digest of Justinian, vol. 2, p. 80. 
the Catholic Church on Roman law..$^{49}$ Instead, a major role in that case was played by the policy of emperors, who relied on Christianity to strengthen their position. It was obvious to F. Bossowski that certain provisions aimed against heretics, such as those laid down in Theodosian Code and concerning the annexation of property owned by temples (C. Th. 10,1,8) ${ }^{50}$ were motivated by fiscal reasons and in particular the desire to fill the empty treasury. ${ }^{51}$

It should be stressed that the scholar was aware of the enormous potential of the research on the issue of the impact of Christianity on Roman law. At the end of his reasoning, he even formulated a research postulate that "research should be conducted in two directions: on the one hand, it should be examined what modifications were introduced into Roman law during the $4^{\text {th }}$ and $5^{\text {th }}$ century after Christ under the influence of bishops exercising judiciary power in civil cases; on the other hand, research should be conducted on church law from ancient times until the moment when the Catholic Church begins to treat thus modified Roman law as its own law and applies it even beyond the borders of the Roman Empire where it has jurisdiction in civil cases." 52

Franciszek Bossowski's attempt to structure the impact of Christianity on Roman law should be valued highly, especially since the issue was not researched extensively in the study of Roman law in the interwar Poland. Franciszek Bossowski's research shows that Poles, too, contributed during the interwar period to the international discussion on the impact of Christianity on Roman law. The author presented in the most comprehensive

49 F. Bossowski, Wptyw chrześcijaństwa..., p. 311; cf. also: A. Dębiński, Ustawodawstwo karne rzymskich cesarzy chrześcijańskich w sprawach religijnych, Lublin 1990.

50 C. Th. 10,1,8 (Impp. Valentinianus et Valens aa. ad Caesarium comitem rerum privatorum): Universa loca vel praedia, quae nunc in iure templorum sunt quaeque a diversis principibus vendita vel donata sunt retracta, ei patrimonio, quod privatum nostrum est, placuit adgregari. Dat. prid. non. feb. Mediolano divo Ioviano et Varroniano conss. (364 febr. [?] 4). [(Emperors Valentinian and Valens Augustuses to Caesarius, Count of the Privy Purse): It is Our pleasure that all parcels of land and all landed estates which are now the property of temples and which have been sold or donated by various Emperors shall be reclaimed and added to Our private patrimony. Given on the day before the nones of February at Milan in the year of consulship of the sainted Jovian and of Varronianus - February 4, 364], as translated in: The Theodosian Code..., ed. C. Pharr, p. 268.

51 Ibidem, p. 312. This was also noticed by Edouard Cuq, as quoted by F. Bossowski:

E. Cuq, Les institutions juridiques..., p. 830.

52 F. Bossowski, Wptyw sądownictwa polubownego..., p. 41. 
way possible the areas where Christianity triggered changes in Roman law, and presented interesting hypotheses as to that impact. Franciszek Bossowski drew attention to ecclesiastical arbitration as a factor that led to spreading of Christian ideas. What is important to stress, he did not claim that all measures that were in line with the Christian outlook had an impact on specific solutions of Roman law, specifically as the Christian ideas were gaining popularity. His views prove that Christianity was not a factor that contributed to a revolution; instead it played a role in long-term evolution..$^{53}$ Based on his assertions, one can also conclude that the Catholic Church on the one hand provided support to the Roman Empire that was, at that time, in a rather difficult situation, and on the other one affected the law and policy of the Empire. ${ }^{54}$ Furthermore, it should be stressed that F. Bossowski's works point to important research problems that should be examined. To sum it up, it is legitimate to conclude that the research by the Vilnius-based scholar offers a valuable contribution to the study of the impact of Christianity on Roman law, also from the perspective of contemporary science.

\section{Bibliography}

\section{Sources}

The Codex of Justinian: A New Annotated Translation, with Parallel Latin and Greek

Text, vol. 1. Introductory Matter and Books I-III, ed. B.W. Frier, Cambridge 2016. The Digest of Justinian, vol. 1-4, transl. ed. A. Watson, Philadelphia 1998.

The Theodosian Code and Novels, and the Sirmondian Constitutions. A Translation with Commentary, Glossary, and Bibliography, ed. C. Pharr, New Jersey 2001.

\section{Literature}

Abraham W., Edykt Medyolański. W 1600-letnią rocznicę, Przegląd Powszechny 1913, vol. 30, no. 119.

Baviera G., Concetto e limiti dell'influenza del Cristianesimo sul diritto romano, in: Mélanges Paul Frédéric Girard. Études de droit romain dédiées à M.P.F. Girard à l'occasion du 60e anniversaire de sa naissance (26 octobre 1912), vol. 1, Paris 1912. Bossowski F., Wptyw chrześcijaństwa na rozwój prawa rzymskiego, Przegląd Prawa i Administracji 1925, vol. 50.

53 Idem, Wptyw chrześcijaństwa..., p. 317.

54 Ibidem, p. 317. 
Bossowski F., Wpływ sądownictwa polubownego biskupów na prawo rzymskie, Rocznik Prawniczy Wileński 1933, no. 6.

Cuq E., Les institutions juridiques des romains, vol. 2. Le droit classique et le droit du Bas-Empire, Paris 1908.

Dębiński A., Kościót i prawo rzymskie, Lublin 2008.

Dębiński A., Ustawodawstwo karne rzymskich cesarzy chrześcijańskich w sprawach religijnych, Lublin 1990.

Insadowski H., Rzymskie prawo matżeńskie a chrześcijaństwo, Lublin 1935.

Lenel O., Geschichte und Quellen des römischen Rechts, in: F. Holtzendorff, J. Kohler, Enzyklopädie der Rechtswissenschaft in systematischer Bearbeitung, vol. 1, München-Leipzig-Berlin 1915.

Markowski H., Edykt nazareński a początki chrześcijaństwa, Sprawozdania Poznańskiego Towarzystwa Przyjaciół Nauk 1937, vol. 11.

Partsch J., Mitteilungen aus der Freiburger Papyrussammlung, vol. 2. Juristische Texte der römischen Zeit, Heidelberg 1916.

Riccobono S., L'influenza del Cristianesimo nella codificazione di Giustiniano, Rivista di Scienza "Scientia" 1909, vol. 5, no. 1.

Stolarek D., Adultera w świetle lex Iulia de adulteriis coërcendis, Lublin 2012.

Szczygielski K., Franciszek Bossowski (1879-1940). Szkic do biografii, Miscellanea Historico-Iuridica 2009, vol. 7.

Woess F. von, Das römische Erbrecht und die Erbanwärter: ein Beitrag zur Kenntnis des römischen Rechtsleben vor und nach der Constitutio Antoniniana, Berlin 1911.

Żeber I., O problemie klasyfikacji "manumissio in ecclesia", in: Prawo wyznaniowe. Przeszłość i teraźniejszość, ed. J. Koredczuk, Wrocław 2008.

Żurek A., Chrystianizacja prawa po "Edykcie Mediolańskim", Vox Patrum 2014, vol. 61 , no. 34 .

\section{Su m m a ry}

The article is intended to present the views of Franciszek Bossowski on the impact of Christianity on Roman law and thus draws attention to the existing output of the Polish science of Roman law in this area. This Vilnius-based Roman law scholar was one of the few researchers in Poland who studied this issue in the interwar Poland. For this reason, the article encompasses an analysis of those of his works in which he touches upon the issue of the impact of Christianity on Roman law. Attention is drawn to the key theses formulated therein as well as his polemics with other scholars. Last but not least, the research postulates formulated by Bossowski are discussed.

Key words: Franciszek Bossowski, Roman law, Christianity 


\title{
Z BADAŃ NAD WPEYWAMI CHRZEŚCIJAŃSTWA \\ NA PRAWO RZYMSKIE W POLSCE MIĘDZYWOJENNEJ: POGLĄDY FRANCISZKA BOSSOWSKIEGO
}

\begin{abstract}
Streszczenie
Niniejszy artykuł ma na celu zaprezentowanie poglądów Franciszka Bossowskiego na kwestię wpływu chrześcijaństwa na prawo rzymskie i tym samym zwrócenie uwagi na dotychczasowe osiągnięcia polskiej romanistyki w tym zakresie. Ten wileński romanista, był jednym z niewielu uczonych, którzy w Polsce międzywojennej zajęli się tą tematyką. Stąd też w artykule analizie poddane zostały te prace naukowe, w których uczony odnosi się do wpływu chrześcijaństwa na prawo rzymskie. Zwrócono uwagę na główne tezy pojawiające się w nich, jak i jego polemiki z innymi uczonymi. Wskazano także na postulaty badawcze sformułowane przez romanistę.
\end{abstract}

Słowa kluczowe: Franciszek Bossowski, prawo rzymskie, Chrześcijaństwo

\section{ИЗ ИССЛЕДОВАНИЙ ВЛИЯНИЯ ХРИСТИАНСТВА НА РИМСКОЕ ПРАВО В МЕЖВОЕННОЙ ПОЛЬШЕ: ВЗГЛЯДЫ ФРАНЦИШКА БОССОВСКОГО}

Резюме

Цель данной статьи - представить взгляды Францишка Боссовского на вопрос о влиянии христианства на римское право и тем самым привлечь внимание к существующим достижениям польского романистики в этой области. Этот вильнюсский романист был одним из немногих ученых, изучавших этот предмет в межвоенной Польше. Следовательно, в статье анализируекются те научные труды, в которых ученый обращается к влиянию христианства на римское право. Внимание было привлечено к основным тезисам, появляющимся в них, а также к его полемике с другими учеными. Также были отмечены исследовательские постулаты, сформулированные романистом.

Ключевые слова: Францишек Боссовский, римское право, христианство 